\title{
Sound and Subjectivity: Polyphonic Composition and its Contribution to Ronsard's Amours de Cassandre
}

Catharine RANDALL

"La Poesie sans les instrumens, ou sans la grace d'une seule ou plusieurs voix, n'est nullement aggreable, non plus que les instrumens sans estre animez de la melodie d'une plaisante voix."

-Pierre de Ronsard, Art poétique (1565).

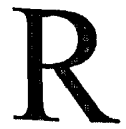

onsard's Amours de Cassandre represents a particularly productive collaborative moment in the history of French literature and the arts: the application of a musical convention to the genre of poetry in order to evoke a nascent notion of subjectivity wherein several voices, as in a contrapuntal composition, can be heard both distinctly and in fusion. Identity, as a result, possesses several options for expression. Individual identity may soar singly and lyrically, or fuse harmonically in unity. There are a variety of rationales for Ronsard's decision to combine musical with literary technique, and a number of ways in which its application and effect can be discerned and evaluated.

Recent scholarship on Ronsard's sonnets has argued that affiliations exist between his poetry and other artistic disciplines and media. For 
instance, Roberto Campo has discussed the tensions between the influx of Italian artists into France in the early 1500 s, the importance of their creations at Fontainebleau, and Ronsard's resentment at the extent of their influence; Campo also suggests that their work nonetheless influenced Ronsard's.' Tom Conley has discerned patterns composed of repeated letters, syllables and lexical elements in Ronsard's poetry, and has speculated that "rets" 2 networks could be gridded over the verbal surface of Ronsard's text, thus adding an almost artifactual texture to the sonnets. ${ }^{3}$ Ronsard scatters ideograms of himself derived from vocalization and orthographic theory, throughout his poems to create a material dimension that assures the immortality of his poetic voice. His poetry is visual in the extreme, but not in the conventional sense: its visuals must be read to be viewed; they are not immediately apparent, but must be constructed by a sensitive and creative auscultation of the text: forms of music, they must first be heard, and sounded. I argue that the visual web of reference which Conley has found is, in fact, a musicological field of resonances: through these semantic patterns, the surface of the sonnet appears lined like a composer's score sheet. However, while the "musicality" of the Amours de Cassandre has received much comment, the relationship between Ronsard's poetry and techniques of what I term poetic polyphonic (containing many voices) and contrapuntal (possessing voices that work in cooperation or in tension with one another to produce dissonance or harmony) composition has not been identified or analyzed. ${ }^{4}$ Ronsard's sonnets possess musical qualities. Among these are his use of word-play and recurrent reference as variants of tonal motif; a sense of working toward completion that is characteristic of both expressive music in general and of Ronsard's poetry; Ronsard's periodic structure, use of repetition, anaphora and alliteration, all of which create a sonorous quality; the ways in which he plays symmetry off against asymmetry, as do musical compositions, through the use of the enjambement and rejet, and other similar stylistic choices.

Contrapuntal music facilitates a rich, multivocal compositional schema in which one voice may soar above another's support, several voices may engage in a conversation, or an individual voice may initiate a calland-response with another distinct voice. Ronsard often speaks specifically in his theory of poetics, the Abbrégé de l'art poétique français (1565), of the importance of music for poetry. Ronsard uses as one model the anacreontic musical conception of the ode. He was thus significantly informed by music as a precursor and as a parallel to his poetic compositions. All of Ronsard's lyric poems were originally intended to be 
sung, as were the voeux, the chansons and the blasons. Indeed, Ronsard envisioned an ideal society in which all sonnets ("little songs") would be sung as well as read. Most of his lyric poems consist of short verses of seven or eight syllables, a flexible rhythm and euphonious sound patterns, distinctly musical qualities.

Ronsard's odes were set to music by contemporary Renaissance composers. In addition, the flowering of polyphonic and contrapuntal music reaches its apogee around the time of the publication of Ronsard's sonnets. Shortly thereafter, patterns and strategies of musical composition significantly altered. Compositions became musically increasingly monovocal what might be called psychologically individualistic. These changes may be attributable to the influence of the Protestant Reformation, a crucible which created a new and different understanding of selfhood and subjectivity. Further, the hymn settings, psalms and other musical compositions of the period became less adorned, more direct, less inclined to musical rhetorical flourishes, as consistent with the Protestant valorization of the biblical stylus rudus, or 'plain style.' In specifically musical terms, such a distinction might be epitomized by the compositions of the Huguenot Claude Lejeune, a contemporary of Ronsard's, or the psalm settings from the French Psalter of 1564 by Claude Goudimel, a former Roman Catholic composer, entirely monophonic, as distinguished from the settings of Ronsard's sonnets to music by Antoine de Bertrand, a Catholic. The self in relation to others, fully developed and autonomous, yet choosing to remain within a social network, is developed by Ronsard; he thereby communicates his traditional Catholic understanding of selfhood-in-relationship or in community, positing this in contrast to individualistic, potentially anarchic, Protestant self-conception. Ronsard, defender of Catholicism (Deffense contre les injures), continued polyphony, therefore, both for purposes of literary communication, as well as for ideological reasons.

\section{The Subjectivities of Music and Poetry}

Ronsard always conceived of his sonnets as pieces of musical poetry, prior to actually setting them to music. Ronsard's appreciation for polyphony caused him to set in motion the verbal interaction of various subjectivities within the sonnet. Polyphony requires plural singing voices, positing a multitude of lyric personae. Ronsard populates his poems with a cross-hatching of points-of-view reminiscent of the harmonic and melodic intersections, variations and embellishments of polyphonic 
compositions. Through a "contrapuntal" notion of composition borrowed from the domain of music and applied to the genre of poetry, Ronsard can make several voices heard. These voices are sometimes distinct, occasionally intertwining; they may at times create a harmonious amalgam, as, for example, when Ronsard constructs an androgyne persona by blending the voice of his "je" with that of the lady, in his sonnets adonisants. This poetic innovation conforms to the definition of polyphony, which is described as consisting of two or more melodies independently treated in a contrapuntal way, and as capable of producing two or more tones simultaneously. Theorists such as Lawrence Kramer and Richard Leppert postulate links among musical practice, the representation of the body, and materialism, or the textual product which is the context for both. ${ }^{5}$ Leppert asserts that "the body produces music, often, from the depths of its own interiority, as with singing and the exhalation of breath into wind-driven instruments. Whatever music is 'about' it is inevitably about the body; music's aural and visual presence constitutes the body." In Ronsard's poetry, embodiment occurs through a strategy of suggestion: the various tones or musical modalities that constitute a speaker's voice are so frequently reiterated as to evoke a concrete block of sound: the visual embodiment of the sonorous speaker. Leppert further adds an important gender distinction to this musical/ compositional construct, one which will prove very significant when we examine later Ronsard's variations on the androgyne motif: "the singular difference between feminine and masculine (neither the same as nor coterminous with female and male) is the constitutive element of every other conceivable relation as regards music's connection to the body." Leppert advances his case within a network of social interactions: "the musical event is perceived as a socialized activity" and a summoning of spatial parameters in which music is perceived and in which music influences the expression of desire: " $\ldots$ a rehearsal of books organizing their sensualities ... guided by musical sonorities that give form to their

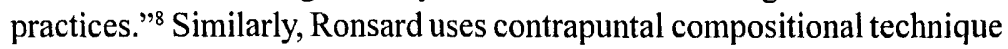
to delineate a space. This space constitutes the arena for a discussion articulated between at least two speakers, as well as the nuances and shadings that emerge from their scripted polyphonic dialogue. While Leppert derives his documentation from seventeenth century artworks that contain representations of the performance of music or of images of musical instruments, I examine poetry composed by Ronsard that contains representations of musical practice, instruments or performance. In many cases, Ronsard's sonnets, which often display descriptions of actual musical instruments such as the lute, are similar to the paintings that 
Leppert examines. Leppert finds, in Dutch seventeenth century interiors, that instruments such as the "lute and violoncelle ... are striking objects in a painting where every object has been carefully chosen; and they occupy considerable, and compositionally 'prestigious' pictorial space" (Leppert 3). Just so, in the artfully arranged economy of Ronsard's textual canvas, those objects described possess great weight and contribute significantly to the movement and meaning of the sonnet: "Music serves as the primary organizing principle [and] ... governing metaphor."

Varieties of what we might call "poetic polyphony" make themselves heard in Ronsard's oeuvre. Sometimes what is heard is an internal, or selfcontained, form of contrapuntal composition. In such compositions, Ronsard's self may entertain a dialogue with an earlier version of himself; with a future projection of himself; or with a contradictory, yet contemporary, shard of himself that has splintered off due to trauma or ambivalence. This latter scenario creates a second, distinctly audible voice, a parallel expression that reinforces, while also subtly distinguishing itself from, the former. At other times, the polyphony is more obvious, with the voice, phantasm, or otherwise determinative presence of the loved one being articulated in the poem, which is conceived as a response to that "other." Other polyphonic poems transcribe the dialogue between poet and friend, poet and critic, poet and patron and poet and poetic influence. In all cases, Ronsard's poetic polyphony enables him, through the use of contemporary musical craft, to construct a unique, personal and subjective persona. His poetry offers a musical manifestation of subjectivity as well as initiates a psychological analysis of the self's nature and speech:

Dơis-je voler emplumé d'esperance,

Ou si je dois, forcé du desespoir,

Du haut du Ciel en terre laisser choir

Mon jeune amour avorté de naissance?

Non, j'aime mieux, leger d'outrecuidance,

Tomber d'en haut, \& fol me decevoir,

Que voler baas, deussé-je recevoir

Pour mon tombeau toute une large France.

Icare fit de sa cheute nommer,

Pour trop oser, les ondes de la mer:

Et moy je veux honorer ma contree

De mon sepulchre, et dessus engraver,

RONSARD VOULANT AUXASTRES S'ESLEVER

FUTFOUDROYE PAR UNE BELLEASTREE. 
In the Sonnets et madrigals pour Astrée, sonnet I, "Dois-je voler, emplumé d'espérance," features two voices, both belonging to the poet: "Dois-je voler? - "Non, j'aime mieux...." The contrast or schism in self is ultimately resolved (as is frequently the case with Ronsard) through mythological comparison that enables him to differentiate his own aspirations from those of his chosen figure of reference. It seems, too, as though temporal progression toward a more mature (and, perhaps, resigned) self enables him to reach this closure. A certain bipolarity of emotion ("espérance/désespoir") translates a version of psychic polyphony that renders an interior struggle, and we learn that the voices are produced by an experience of pain that needs to be resolved: "mon jeune amour avorté de naissance" links amour and avorté in an initially positive association through the repetition of the soft $a$ sound; however, the homophonic similarity between vort and mort aborts the project and perpetuates the poet's anguish with hard, conflicted sounds,

J'espere \& crains, je me tais \& supplie,

Or je suis glace $\&$ ores un feu chault, J'admire tout, \& de rien ne me chault, Je me delace, \& puis je me relie.

Rien ne me plaist si non ce qui m'ennuye, Je suis vaillant, \& le cuoeur me default, J'ay l'espoir bas, j'ay le courage hault, Plus je me picque, \& plus je suis restif, J'ayme estre libre, \& veulx estre captif, Cent foys je meur, cent foys je prens naissance.

Un Promethée en passions je suis,

Et pour aymer perdant toute puissance,

Ne pouvant rien je fay ce que je puis.

We see the same sort of pattern in Amours de Casssandre. In sonnet XII, "J'espère et crains, je me tais et supplie," we hear the tone of a conversation that Ronsard improvises for himself in his head. The discussion is solipsistic, focused on the 'je,' such that Cassandre seems merely the pretext for a detailed compulsive self-examination and an obsessive auscultation of the self's sentiments: "plus je me pique, et plus je suis rétif. ..." Ronsard resolves the conflict, here, too, through reference to a mythological model who has endured similar trials Promotheus and, this time, knows himself by wholly recognizing himself in, and adopting, his model: "Un Promethée en passions je suis." The contrapuntal composition features, thus, an oscillation in dialogue form between Ronsard's intellectual, ratiocinated self, as contrasted with his desiring 
self. In the end, the desiring self triumphs, so that the possibility of hope the possibility of possibility! with which Ronsard had begun the sonnet ("j'espère") remains bound and merely virtual.

Similar blockages occur elsewhere in the sonnet. For instance, a movement toward the polyphony of self speaking to self can be obstructed. Such hindrance often features through the presence of an actual musical artifact the ghostly suggestion of sound which the hand is restrained from playing. This inability to strike a chord suggests a similar incapacity to sound the depths of the self, to express a yearning, or to communicate a feeling to another:

Bien mille fois \& mille j'ay tenté

De fredonner sus les nerfz de ma lyre,

Et sus le blanc de cent papiers escrire,

Le nom, qu'Amour dans le cueur m'a planté.

Mais tout soubdain je suis espovanté,

Car sa grandeur qui l'esprit me martyre

Sans la chanter arriere me retire

De cent fureurs pantoyement tourmenté.

Je suis semblable à la prestresse folle,

Qui bégue perd la voix \& la parolle,

Dessoubz le Dieu qu'elle fuit pour néant.

Ainsi picqué de l'Amour qui me touche

Si fort au cuoeur, la voix fraude ma bouche,

Et voulant dire ne vain je suis béant.

In the Amours de Cassandre, sonnet XXVII, "Bien mille fois et mille j'ai tenté," the poet is confronted by the taunting presence of a silent lyre, the emblem both of poetic creativity and of personal, amorous expression. The instrument substitutes for the poet himself, as the repetition of the possessive pronoun "ma" in "ma lyre" makes clear, and both the instrument and the poet are mute ("Qui bégue perd la voix et la parolle"). Both passion and inspiration are imperilled by this silencing: Ronsard evokes the oracle Cassandra and figures her, too, as voiceless. Instead of the clamor of possible poetic voices suggested by this poem, a deafening silence prevails. This sonnet acts as a visualization of the need for the concept that Ronsard is attempting to develop, that of polyphonic poetic composition, for it represents the inability to pen poetry, to prophesy or to express passion, as though to prove the principle of the following assertion:

The attribution of subjectivity to an individual is just beginning [in the sixteenth century]: autobiographies appear; there is a 
great interest in letter writing; portrait art and sculpture become personalized; there are changes in people's ideas of intention, sin and atonement. But these developments do not imply a subjectivity comparable to our own modern one. The way to a wholly free choice of expression and representation has not yet been cleared, or even prepared. The creation of personalized worlds remains beyond literary capabilities. ${ }^{10}$

Yet Ronsard will move beyond this impediment, and the representation of it, for he finds the influence of music to be a new avenue through the problem. By applying the medium of music to the genre of poetry, he dislodges the obstacle to subjective articulation, finding it best developed as it works itself out through a choral phenomenon, becoming most fully itself when it responds to another, or to another 'self.' This works in the following way: music theorist Jerold Levinson explains that any expression functions in terms of "hearing as," in which the "imaginary subject" plays a prominent role. ${ }^{11}$ Thus, in writing for an audience be it his loved one, or simply his reader Ronsard composes musically in that he conceives of his emotion as something that must be communicated to another in order to exist. His subjectivity is already latently polyphonic; his new understanding of poetic composition simply actualizes the complexities of contrapuntal communication. Ronsard develops his complex, personalized understanding of individual identity through an incorporation of musical elements into his poetry, then sketches an evolution toward a reworking of models (musical and literary such as Pindar, Homer and Horace). ${ }^{12}$ Later, toward the end of the Amours, we discern a more "narrative" conception of composition.

\section{The Materiality of Music and of Poetry}

In the Amours de Cassandre, the list of featured musical instruments is limited and specific. Ronsard refers only to the lyre ${ }^{13}$ and the lute..$^{14}$ There is a reason for this selection: the lyre and the lute are the lyrical instruments par excellence, those associated, since Antiquity, with "personal" expression ${ }^{15}$ such as the lament, the complainte, or with a reaction to beauty, nature or the emotion of love. The "personal" tenor associated with possessing and playing these particular instruments is underscored by the personal pronoun habitually attached to them by the poet: invariably, he designates the instrument as a sort of partner in a relationship ("ma Lyre"; "ta lyre"; "son luth"). In addition, nearly always in the Amours de Cassandre, the musical instrument is introduced in the 
first stanza, thus explicitly setting the remainder of the poem within a musical context. However, as I have noted above, the function of the instrument mutates gradually in this sonnet collection: while it initially identifies a poem that is more "musical" than otherwise, it eventually designates Ronsard's awareness that musical compositional technique can yield a new narrative form of poetry more apt for personal expression. This change is seen in the gradual shift from terms such as "chanter,"16 "plaindre" 17 and "lamenter" 18 associated with musical instruments, to "conter," 19 the musical instrument as the "secretaire" 20 and the act of poetic reception not as one of hearing but of "lisant" 21 a text wherein an emotion is "empreinte." 22 Music and narration may conjoin in a later poem, symbolically summarizing Ronsard's new lyric poetry, as in this sonnet, where "lyre" and "encre" seem equivalents:

Dépends du croc ma lyre chanteresse:

Je veux charmer si je puis la poison

Dont un bel oeil enchante ma raison

Par la vertu d'une oeillade maîtresse

Donne-moi l'encre et le papier aussi,

Je veux tracer la peine que j'endure. ... 23

Ronsard's goal is bound up with the nature of representation, a search for the most effective techniques for evoking the reality of personal, subjective experience. He moves toward a more representational art (writing seen as painting a portrait) ${ }^{24}$ than evocative (lyrical, musical). Yet he does not polarize or divorce the two: within the later, more "representational" or pictorial poems, the musical element abides en filigrane as the strategy whereby Ronsard arrived at this point: the lyrical evocation of one, or several, subjectivities, the polyphonic rehearsal of a conversation among multiple selves or diverse interlocutors, is ultimately what enables Ronsard to "paint" a definitive manifestation of his experience. The very painterly "Epitre à Janet" (1555) epitomizes this trend in Ronsard's poetic creation:

Peins-moi...

Sur ce tableau les beautés de m'amie

De la façon que je te les dirai

Il suffit bien si tu la sais portraire

Telle qu'elle est, sans vouloir déguiser

Son naturel pour la favoriser

Peins-la-moi donc qu'elle semble parler 
...qu'elle semble pleine...

Persuadé de raisons je m'assure

Que la beauté qui ne s'apparaît, doit

Etre semblable à celle que l'on voit. ${ }^{25}$ Musicality remains, for him, the way to apprehend subjective sentiment.

Several of the sonnets in the Amours de Cassandre (1552) were set to music during the years 1552 to 1617 by more than thirty contemporaries of Pierre de Ronsard. The five most important composers were Certon, Janequin, Goudimel, Muret and Bertrand. Others include P. Clereau (Les Odes, 1575), de Monte (Les sonnets, 1576), Guillaume Boni (Les sonnets), J. De Castro (Les odes et sonetz). ${ }^{26}$ The most popular sonnet to be set to music was "Mignonne allons voir si la rose" (1553), and the Amours de Cassandre (1552-1553) were by far the most frequently set to music of all of Ronsard's oeuvre. None of the Sonnets pour Hélène set to music was ever performed. This move away from adaptability to music after Cassandre substantiates the thesis that Ronsard's poetry later, and progressively, became less lyrical, personal and evocative and more painterly, representational and intellectualized.

The sonnets warrant examination for their selection (to the exclusion of others). What may have been the criteria for selection? These sonnets seem to have possessed an appeal that was not only public but, in some measure, also 'private': they spoke to the subjective sensibilities of the composer who discerned, distilled in their verses, experiences with which (to use our modern parlance) he could 'identify.' I do not want to strain the thesis of subjective appeal, or capacity to elicit the hearer/composer's identification with the poet's experience. Admittedly, there were also technical reasons for such selections, among them the ease with which the sonnets of 1552 could be set to prototypes of only four musical scores (due to their tendency to begin the tercet component with either a masculine or feminine rhyme, a simple and unvaried format to which Ronsard adhered through the Amours de Cassandre.)

One composer, Antoine de Bertrand, who set to music more than thirty-five of Ronsard's sonnets, speaks in his Preface about the sort of subjective screen that Ronsard's poetry makes available for the expression of his, Bertrand's, personal expression: ' $j$ 'espère vous faire long tams y a, quand espris de mesme flamme, que nostre poète françoys, je m'estudioys à représenter les effaitz de tes amours et des miennes tout ensemble."27 The deliberate appropriation of Ronsard's "flamme" to be that of Bertrand, and the latter's insertion of himself into the former's subjective experience of love, speak both to the universalizing quality of lyric expression as 
well as to the growing awareness of a 'self' who passes through events in ways that sometimes differ from, yet may coincide with, the responses that others have to similar events. This flexible plasticity of Ronsard's sonnets may derive, at least in part, from his role as "chantre des amours d'autrui:" ${ }^{28}$ from 1560 on, many illustrious patrons commissioned Ronsard to pen poetry reflecting their amorous experiences. When similarity exists, a conversation may ensue: in contrapuntal and polyphonic music,

musical boundaries may . . overlap. One phrase may begin before another has ended, and a single note may be heard both as the end of one phrase and the beginning of another. . . Phrases may be dove-tailed, so as to crisscross through the texture of a piece ... our ability to perceive these internal boundaries, and to hear them occurring in separate but concurrent phrases [is key]. ${ }^{29}$

Polyphony is the musical vehicle that facilitates such a literary discussion. Ronsard describes the feeling both of mutuality and of differentiation that characterizes his love for Cassandre in such a polyphonic way, the pronouns marking pauses where two interlocutors take breaths before enunciating their subjective positions in this dialogue that binds the two (virtual) speakers in a symbiotic communication:

Mon tout, mon bien, mon heur, ma connaissance

Vint de ton oeil; car pour nous lier mieux,

Tant nous unit son feu présagieux,

Que de nous deux il ne fit qu'une essence.

En toi je suis et tu es seul en moi,

En moi tu vis et je vis dedans toi,

Tant notre amour est parfaitement ronde.

Ne vivre en toi ce serait mon trépas. ${ }^{30}$

As Roger Scruton instructs in The Aesthetics of Music, music has a personality: "melody is heard as a musical individual." 11

\section{Multiple Personalities}

Polyphony can conjoin, harmonizing several voices, but it can also differentiate, inscribing tension between speakers whose voices refuse to blend or fuse completely. Several of Ronsard's 'androgyne' sonnets illustrate well this latter condition. Just as "counterpoint ... depends on the composer's ability to switch our attention from part to part, while maintaining an even texture," ${ }^{32}$ so, too, Ronsard's 'androgyne' sonnets 
hold in exquisitely calibrated relation the two character roles incarnated in the one, multi-symbolizing, body. The androgyne is, indeed, a recurrent motif in Ronsard's poetry, one not always merely suggested musically, but actually stipulated, narratively, as in the "Elégie à Muret":

Il s'habilla des habits d'une femme

Et d'un Héros devenu damoiseau,

Guidait l'aiguille, et tournait le fuseau. ${ }^{33}$

Polyphony possesses a foreground and a background, evoking a resonant 'inner voice.' The alternation between the point-of-view of one posited persona, and that of another, in Ronsard's 'androgyne' poems imitates this three-dimensional acoustic space. Polyphony offers anaesthetic experience with "double intentionality ... [in which] one thing is seen another." ${ }^{34}$ The androgyne embodies such "double intentionality," a polyphonic construction of personality in which multiple persona play off each other.

Que dittes vous, que faites vous mignonne?

Que songez-vous? Pensez vous point en moy?

Avez vous point soucy de mon esmoy,

Comme de vous le soucy m'espoinçonne?

De vostre Amour tout le coeur me bouillonne,

Devant mes yeux sans cesse je vous voy,

Je vous entends absente, je vous oy,

Et mon penser d'autre Amour ne raisonne.

J'ay vos beautés, vos graces \& vos yeux

Gravez en moy, les places \& les lieux

Ou je vous vy danser, parler \& rire.

Je vous tien mienne, \& si ne suis pas mien,

Je me perds tant au bien que je desire,

Que tout sans luy ne me semble estre rien.

In Sonnet XI, "Que dites-vous, que faites-vous, mignonne?," Ronsard composes a sort of interior debate, a prosopopoeia of the self, using the pronouns "moi" and "vous" and the possessive adjectives "vos" and "mes." "Polyphony played a major role in generating ... harmonic language . . . by deriving harmonies from the inner voices." 35 Thus, polyphony possesses a proto-narrative component, in that its nature derives from "audible relations, construed intentionally." 36 The theater for the willed (re)construction of the personality is Ronsard's body: this is a psychological form of possession, in which the part of the self perceived as 'other' or, perhaps, that 'other' so intensely desired by the self that it seems an errant part of the self comes to occupy the space of the self, to 
supplant the self. The 'other' is an obsession of the self ("Devant mes yeux sans cesse je vous vois, / Je vous entends, absente je vous ois"). ${ }^{37}$ In addition, "je" and "vous" rub up against each other in such propinquity that "je" begins to take on some of the traits of "vous," and vice versa: The troubled syntax suggests that the self is being progressively occupied by the "other," or is yielding its identity in deference to a more powerful and pervasive presence: "absente je vous ois": we know that "vous" is the antecedent for "absente," but "absente"'s proximity to "je" implies otherwise, also suggesting some lack of gender fixity in the self's perception. In fact, the self-image has become the portrait of another; like an unfaithful or enchanted mirror, the visage reflected back to the viewer is not his own:

J'ai vos beautés, vos grâces et vos yeux

Gravés en moi ...

Je vous tiens mienne, et si ne suis pas mien. ${ }^{38}$

This substitution becomes symbiosis as the "other" infiltrates the physiological system:

Vous êtes seule en qui mon coeur respire,

Mon oeil, mon sang, mon malheur et mon bien. ${ }^{39}$

What does this phenomenon of possession have to do with musicality? Simply put, the compositional structure is polyphonic, built on a (false) dialogue, an exchange of echoes and motifs representative of two personae. The contrapuntal construction of the poem weaves together melody and harmony, two parts into a whole, as does music. This phenomenon is consistent with that produced by polyphony: a collapsing of difference into a unity that nonetheless retains traces of that essential otherness. "When music becomes polyphonic . . . the moods tend to collapse ... into the diatonic scale . . . it preserves just those notes of a mode which can be sung together without ... dissonance. It is [a] 'reduced' form ... as the voices modify." 40 The resulting redetermination of identity is simultaneously and challengingly both singular (Ronsard is absorbed by his love interest) and dual (he retains, as androgyne, his and her characteristics distinct together within the new, paradoxical union). Thus, two and even, perhaps, a third, 'new,' voice formed from the two can be heard, as in polyphonic music: in part-writing, the triad is constructed as part of a process. The specific sonorous quality of the sonnet further evokes the two voices or personae. We hear the repetitious, chacteristic /s/ of Cassandre (which, in other poems, is visually imitated by sinuous groupings of/s/ recalling her winding tresses: "que songez-vous, pensezvous ... souci . . . souci . . . sans cesse je vous vois" and the more somber 
nasal "on" of "mon émoi ... m'espoinçonne ... mon penser d'autre amour ne résonne .. . mon coeur ... Mon oeil ... mon sang, mon malheur et mon bien. ..." The third entity meshes the two sounds (/s/ and /on/): "vous êtes seule en qui mon coeur respire / . . Mon sang. . .."

\section{Conclusion}

Many different things are going on in Ronsard's contrapuntal compositions, among them analogies with multiple personae, voices, dialogue with other poets and conventions. In The Grammar of Creation, George Steiner talks about true literary creation as being polyphonic:

Only God's self-address is, strictu sensu, a monologue. That of even the most 'original' artists, taking this word at full strength, is polyphonic.... Other voices urge the disequilibrium, the loss of sterile poise, which triggers imagining into motion. By these voices, analytic thought is made homeless to itself. It seeks to inhabit alternative forms ... [and] alternative incarnations. ${ }^{41}$

By wedding contemporary musical technique to his poetic craft, Ronsard constructs an evocative, multi-voiced oeuvre that initiates the expression of the early modern self.

Fordham University

\section{Notes}

1. Roberto Campo, Ronsard's Contentious Sisters: the Paragone between Poetry and Painting in the Works of Pierre de Ronsard (Chapel Hill: North Carolina Studies in the Romance Languages and Literatures, 1998).

2. Ronsard himself uses this term many places in his poetry; for example, see "leurs retz," sonnet CXXIV, "L'an mil cinq cent contant quarante \& six," Amours.

3. Tom Conley, The Graphic Unconscious.

4. Scholars such as Henri Weber have remarked on the extraordinarily evocative quality of Ronsard's patterns of rhythm: "Ronsard, par le jeu du système, nous fait sentir l'élan imaginatif, l'impatience qui l'emporte vers la beauté, l'alternative frémissante d'exaltation ou d'abattement ... le rhythme [de ses sonnets] est presque toujours sans défaut," xii, Introduction, Les Amours de Ronsard. 
5. See, for instance, Richard Leppert's The Sight of Sound: Music, Representation, and the History of the Body, and Lawrence Kramer, Music as Cultural Practice, 1800-1900.

6. Leppert, The Sight of Sound xx.

7. The Sight of Sound xxii.

8. The Sight of Sound xxiv.

9. The Sight of Sound xxvii.

10. Gunter Gebauer and Christoph Wulf. Mimesis: Culture, Art, Society, trans. Don Renean (Berkeley: U of California P, 1992) 83. Emphasis added.

11. Levinson, cited in Scruton, The Aesthetics of Music 350.

12. Cf. Sonnets CC "Jeune herculin, qui des le ventre sainct," CLXXXVIII and "Ces flots jumeaulx de laict bien espoissi," for instance.

13. See, for example, sonnets XXVII "Bien mille fois \& mille j'ay tenté," XXXVI "Pour la douceur, qu'amour veut que je sente," CXXIII "Dy l'un des deux, sans tant me desguiser," CLXXV "Amour et Mars sont presque d'une sorte" and Elégie.

14. See, among others, sonnets XXXVIII "Doulx fut le traict, qu'Amour hors de sa trousse," LX "Comme un chevreuil, quand le printemps destruit," CXV "Bien que six ans soyent ja coulez derriere," and CCIX "je suis, je suis plus aise que les Dieus."

15. I put 'personal' in quotation marks since I am arguing in this article that the adjective only applies in the form of a prefiguration: individual identity as a self-conscious form to be displayed before a literary public is, in Ronsard's time, only just beginning (in large part thanks to him). It is doubtless also significant that when Ronsard published his first Oeuvres (1560), he seems to have relied on an exclusively chronological order for the sonnets; yet in 1578 Ronsard published the poems in separate groupings (Cassandre, Marie) apparently oriented around the notion of the inspiration of the woman, attesting to some sense of each woman's distinct 'personality' or, to make a more modest claim, at least to two different reactions on Ronsard's part to two dissimilar love objects. Henri Weber says in his introduction to the Amours that "Ronsard va dès lors s'efforcer de distinguer plus nettement par le ton les deux recueils et, en même temps, de les centrer davantage, l'un sur la personnalité de Cassandre, l'autre sur celle de Marie. ..." (emphasis added, $1 \mathrm{x})$.

16. Sonnet LXXVII "J'ai cent fois épreuvé les remedes d'Ovide."

17. Sonnet CXXVI "Quand en songeant ma follastre j'accolle."

18. Sonnet CXXIX "Je parangonne à ta jeune beauté." 
19. Sonnet CLX "Saincte Gastine, heureuse secretaire."

20. Sonnet CLXV "En escrimant un Démon m'eslança."

21. Sonnet CLXVIII "Ce fol penser pour s'en voler plus hault."

22. Sonnet CLXXVI "Jamais au cuoeur ne sera que je n'aye."

23. Sonnet CXCIX "Que Gastine ait tout le chef jaunissant."

24. "Lisez" and "voyez" are more frequently linked. See, for instance, Sonnet CCIX "Je suis, je suis plus aise que les Dieus."

25. "Epitre à Janet."

26. Henri Weber, introduction, Amours, lxvi.

27. Jean-Pierre Ouvrard, introduction to "Musique d'abord: Anthoine de Bertrand, Amours de Ronsard," Ensemble Clément Janequin, Harmondi mundi, (Arles: France, 1985). Emphasis added.

28. Henri Weber, introduction, Amours xxiii. Admittedly, this phenomenon emerges later in date than the composition of the Amours de Cassandre.

29. Scruton, The Aesthetics of Music 42-43.

30. Sonnet CXLI "Chanson." Emphasis added.

31. Scruton, The Aesthetics of Music 40. Emphasis added.

32. Scruton, The Aesthetics of Music 46.

33. "Elégie à Muret."

34. Scruton, The Aesthetics of Music 86.

35. Scruton, The Aesthetics of Music 270.

36. The Aesthetics of Music 271.

37. Sonnet XI "Que dittes vous, que faites vous, ma mignonne?"

38. Sonnet XI "Que dittes vous. .."

39. Sonnet XI.

40. Scruton, The Aesthetics of Music 247.

41. Steiner, The Grammar of Creation 88.

\section{Works Cited}

Van den Borren, Charles. "Les musiciens de Ronsard." Revue musicale 3 (May, 1924): 45-64.

Carpenter, Nan Cooke. "Ronsard's Préface sur la musique." Modern Language Notes 75 (1960): 126-33.

Clark, Suzannah, and Alexander Rehding, eds. Music Theory and Natural Order from the Renaissance to the Early Twentieth Century. Cambridge: Cambridge UP, 2001. 
Comte, Charles, and Paul Laumonier. "Ronsard et les musiciens du XVIe siècle," Revue d'histoire littéraire de la France 7: 341-48, 1900.

Conley, Tom. The Graphic Unconscious. Cambridge: Cambridge UP, 1992. Expert, Henry. Les maitres musiciens de la renaissance française. Reprint New York: Broude, 1966.

Jeffrey, Brian. "The Idea of Music in Ronsard's Poetry." Ronsard the Poet. Ed. Terence Cave. London: Methuen, 1973.

Jourdain, Margaret, trans. "Letter on the Deaf and Dumb." Diderot's Early Philosophical Works. Chicago and London: The Open Court Publishing Company, 1916.

Judd, Cristle Collins. Reading Renaissance Music Theory: Hearing with the Eyes. Cambridge: Cambridge UP, 2000.

Kramer, Lawrence. Music as Cultural Practice: 1800-1900. Berkeley: U of California P, 1990.

Laumonnier, Paul. Ronsard: oeuvres complètes. 20 vols. Geneva: Droz, 1914-1975.

Leppert, Richard. The Sight of Sound: Music, Representation and the History of the Body. Berkeley: U of California P, 1993.

Parrish, Carl. A Treasury of Early Music: Masterworks of Middle Ages, the Renaissance and the Baroque Era. New York: Dover Publications, 1986.

Scruton, Roger. The Aesthetics of Music. London: Oxford UP, 2001.

Silver, Isidor. "The Marriage of Poetry and Music in France: Ronsard's Predecessors and Contemporaries." Studies in Honor of James Hutton. Ithaca: Cornell UP, 1975.

Steiner, George. Grammars of Creation. Originating in the Clifford Lectures for 1990. Hartford: Yale UP, 2001.

Thiboult, Geneviève, and Louis Perceau. Bibliographie des poésies de Pierre de Ronsard mises en musique au xvie siècle. Geneva: Droz, 1941.

Weber Henri, ed. Ronsard: Les Amours. Paris: Garnier, 1963. 